\title{
Psychological aspects of representation of Trekhostrovsky sanctuary as a new direction of scientific tourism
}

\author{
Anna Valerievna Chernyaeva ${ }^{1}$ \\ Volgograd State Agricultural University, Department of Pedagogy and Methods of Vocational \\ Training, Volgograd, Russia
}

\begin{abstract}
The development of scientific and educational tourism in the conditions of modern reality is accounted for by a number of reasons, but its purpose remains unchanged - it serves as an information source and a means of communication. In the context of provisions of the World Tourism Organisation, Russia is in possession of extremely promising areas for scientific tourism; therefore, scientific tourism may be regarded as a product of an agreement between scientists, which is supposed to provide due conditions for the formation of competitive scientific results within the framework of prospective and demanded research. This article attempts to consider the prospects for the development of scientific tourism in Volgograd region and to analyse and identify the possibilities of using the available corpus of knowledge about Trekhostrovsky sanctuary for continued research in the field of scientific and educational tourism involving the resources of the Southern Federal District. The modern trends in professional studies exploring the ethnographic status, historical and cultural heritage of Russia's unique resources represent one of the universal categories of scientific tourism and are treated in terms of natural cognitive features within the subject area of psychological anthropology in the context of studying the system of relations between culture and personality on certain conditions and in certain forms. It is quite obvious that the federal and regional resources represented by natural and anthropogenic objects in Russia can act as a competitive product of innovative scientific tourism. The potential for the development of scientific tourism in Volgograd region lies in the peculiarities of the anthropogenic objects of Donskoy Nature Park, as can be exemplified by the religious and mythological traditions of the unique Trekhostrovsky sanctuary, with generalisation of the available scientific materials, based on the analogy of cultural components inherent in the stone and fire worship cults.
\end{abstract}

Keywords: scientific tourism, religious and mythological traditions, cult symbols

\section{Introduction}

\footnotetext{
${ }^{1}$ Corresponding author: amba8@mail.ru
} 
The present and the future of the world scientific and cultural heritage exists tangentially in relation to the past, while the interest in the study and development of scientific tourism is of utmost importance as a growing trend. In this context, Volgograd region has very promising regional resources, as concerns prospective research of natural and anthropogenic objects representing a competitive product which can subsequently serve as a basis for the development of scientific tourism and for extension of the domestic-market range of tourist services, including those of educational character.

The regional attractions of Donskoy Nature Park have a significant potential and a special status of nature-rich geographic place within and beyond the Don River bend. The overall territory of Donskoy Nature Park covers 62,000 hectares; the park has 52 springs (with more than 50 underground spring outlets of varying extents of mineralisation), bottom-land meadows, lakes, mort lakes, hardly passable chalk terraces; the fauna comprises 125 animals listed in the Red Book.

It seems appropriate to consider the cultural investment in Trekhostrovsky sanctuary located on the territory of Donskoy Nature Park of Ilovlinsky district within Volgograd Region as an important aspect of sociocultural and psychological determinant for the development of scientific and educational tourism in the Southern Federal District.

The object of consideration of the present article is Trekhostrovsky sanctuary; the mythological sacral complex of the Volga-Don-area population is reconstructed and analysed on the basis of folklore and ethnographic materials, as a resource for scientific and cognitive potential with a psychological dominant viewed through culturological significance of exploration maturity of the given archaeological monument. The basis for this consideration is the actual existence of the unique Late Bronze Age archaeological site in the Volga-Don region.

\section{$2 \quad$ Methods}

The article analyses the target indicators of the tourist flow on the territory of Volgograd region along with the regional tourism, as concerns internal and inbound tourism in Volgograd region. The authors, when studying the ethnic traditions, generalised the works exploring the corpus of archaic cultural traits on the basis of the method "discovery of the new in the old". There are very few special works on the subject of the study; therefore, the research apparatus of the socio-cultural comparative analysis of literary sources was carried out through interpretation of the cultural tradition content and evaluation of the material objects heritage mediated by symbolic and spiritual values.

\section{$3 \quad$ Results}

The analysis of targeted figures of the tourist flow on the territory of Volgograd Region within the period from 2017 to 2019 showed a steady growth dynamics, respectively: in 2017 - 903 thousand visitors, in 2018 - 1,100 thousand and in $2019-1,199$ thousand. A significant decline in sale of tourist packages, as concerns inbound tourists visiting Volgograd region, i.e. the flow, which includes both external and internal consumers of tourist services, was observed in 2020, amounting in total to 380.5 thousand, which can be explained by the global situation of restrictions imposed in connection with the spread of coronavirus infection and limitations on people's travel [1].

Having studied the benchmark indicators for major directions of development of Volgograd region, specifically, the active leisure sectors incorporated within a collective group "Tourism", the authors outlined 5 priority areas on the territory of Volgograd region within the above area (cultural/educational, ecological, cruising, health improving and 
event activity tourism) [2]. According to the statistics, scientific tourism is not singled out separately as a priority area. In this regard, an analysis was undertaken, considering the worldview-specific differentiation of opinions on the origin of Trekhostrovsky sanctuary as a new direction within the scientific cluster of excursion routes.

In the historical discourse, sanctuaries represent several types of sacred places of round shape for veneration of gods and ancestors through fire taming (sacrificial fire, hearth furnace). It is worth noting that the sacred places of worship were located far from populated areas' borders and were associated with relatively rare ancestral ritual events (great holidays, significant events marked by a clan, etc.) [3].

The anthropogenic object represents a hill surrounded by a moat; the diameter of the structure varies within 200 metres. According to the research data (chemical analysis of soil samples), the construction of the sanctuary was carried out stepwise in the Bronze Age; the furnace operation period covers one hundred years. The study of three levels of buried soils of Trekhostrovsky sanctuary, that showed alternation of deluvial and soil-forming processes, as well as the chemical analysis of the combustion product slag, bear evidence of the combustion temperature reaching $1300 \mathrm{C}^{\mathrm{o}}$, meanwhile the question on its actual purpose remains open. The radiocarbon dating of selected samples refuted the previously considered version of industrial iron smelting [4]. The construction stages supposed digging a foundation pit which was further filled up with a liquid clay solution -most likely, this involved the act of erecting a foundation for the altar. This aspect lets one suppose that Trekhostrovsky sanctuary had a status of a place of worship that was further reconstructed as a mythological sacral complex within a single archaeological site, where the fire was a structure-forming element of the stone cult (altar constructed). The attempts to bring the religious site into correlation with any culture proved to be unsuccessful, since during the excavations no settlements or human artefacts were found around the object - this gives rise to the question as to its intention.

\section{Discussion}

The unquenchable fire represented a mythological universal of life and death. The semantics of rituals with burnt-offering fire and smoldering smoke ascending to the sky is reflected in the averters guarding the borders of dwellings and land holdings (ancestral homeplace), in rituals of addressing the ancestors' souls [5]. The ancient notions of the sacred centre of the universe, those associated with fire worship rituals, personified the initiation rite through symbolic blinding in various religious and mythological traditions of the mankind [6]. It is quite obvious that in the conditions of prelogical thinking within the collective ideas about mystical co-involvement, the identity of the fire, the altar and the priest relied on the ritual roots proclaiming diversity of representations of the universe [7, $8]$.

In this context, the representation of Trekhostrovsky sanctuary may be considered as a hypothesis on the origin of the concentration (abode) of the supreme deity prototype (the exhibited unity presented in the form of its mediated components: the sensibilia and other worlds) through mystical involvement of the conceptual nature of the foundation stone (altar) cult. Trekhostrovsky sanctuary is a fiery altar in a stone bowl or a prototype of the "navel of the earth", a natural and at the same time man-made omphalos symbolising the centre of the universe in many ancient cultures [9]. The complex and ambiguous symbolism of the lexeme "stone" is reflected in different cultures; the meaningful context here is understood as "a kind of foundation, as a centre of the world, as a source of two powers of cosmos - fire and water", and as a "place of power" [10-12]. Then the sacred meaning of the combination of the two cults (fire and stone) represents a system designed to comprehend the spirituality of the world (turning into a stone). Symbolically, in man's 
consciousness, after one has lived through that moment (inner flame-like urge towards cognition or vital energy), he continually verifies his deeds along this path and compares them with what he has already experienced. In this aspect, it is a path of spiritual development or acquisition of spiritual robustness [9, 13]. Gaining spiritual robustness, a person becomes able to compare, analyse and develop his substance (holiness: physical, spiritual). Such an entity becomes self-sufficient and develops through itself faster than those who have not experienced spiritual anguish and have not answered the question what they live for. Personification of the process of man's inner involution presumes transformation of his lower "I" into a higher ego through transformation of the soul (fire), spirit (stone) and body (earth).

In this regard, a flexible system of people's opposing actions relative to creating a place of worship matches the representation of ideas about the World Mountain or the Centre of the World in different religious and mythological traditions in respect of some designated fragment of reality (Navel of the World: Cusco, Omphalos, etc.) [9]. On the one hand, creating a sanctuary shaped like a circle could mean a generalised fixation of the sacred centre. On the other hand, the apocalyptic description of extinction of the furnace and erection of a limestone mound with a domed elevation reflects the dynamics of changes in the worship practices and their semantic load, effectuated through renewed ritual customs [14].

\section{Conclusion}

The generalisation of possible analogies in explaining the origination of Trekhostrovsky sanctuary makes it possible to draw some conclusions:

First, the designation "fiery altar" considers the phenomena that are much different in form, essence and origin. The common feature in all aspects is the similarity of superstitious ideas within a certain ethnic group, which concerns veneration of the fire and the stone in relation to which certain ritual acts are performed, while the abstract nature of the general concept of its existence is possibly limited to cognitive use, though it does not deprive a researcher of the right to use the metaphorical terms as a means of conceptualising the analysis of the reality from two viewpoints - the source and the parameter [9].

Second, the variety of the national stone and fire cults well explains the direct dependence of the forms of religious and mythological concepts (cult-specific actions, cult symbols) on the historically determined life conditions manifested through material activity, which is in due conjunction with the national moral system of values including eventfulness of the surrounding reality, which may be the case of the reviewed lexemes "stone" and "fire altar" [15]. The metaphorical functions of stone therapy are diverse, provided that the mythological views of the stone involve life transformation [13]. The stone is a conventional figurative element which represents an image in the folk-mythological interpretation of ritual traditions, a life model (psychological, logical, mythopoetic) that mirrors the main elements and parameters of the world order.

Third, the isofunctionality of the stone and fire cults through the representation of Trekhostrovsky sanctuary reflects the integrated manifestation and preservation of traditions of the Late Bronze Age population of the Volga-Don area. The invariance of cult symbolism in respect of the sacred fire altar is a sign of isofunctionality of the stone and fire cults (as genesis of the spirits of fire-breathing mountains: "mud volcanoes" among Kamchatka Itelmes; worship of the blacksmith god Vulcan by the inhabitants of Sicily; worship of god Ahura-Mazda with externalization of Atar in the Zoroastrian culture, etc.).

The overall analysis shows that Trekhostrovsky sanctuary, while conveying a vast information about the world and the man, is an object permitting to fix new forms of 
mentality in the world culture, new ways of man's cognising the global landscape and his self-identification in the surrounding reality. This makes the development of the issue in question relevant, since it reflects man's culture and mentality, his psychological characteristics and cultural factors - all this being simultaneously an innovative project in the area of scientific tourism, requiring further research.

\section{References}

1. Postanovlenie ot 9 aprelya 2019 goda № 168-p Ob utverzhdenii gosudarstvennoi programmy Volgogradskoi oblasti "Razvitie turizma v Volgogradskoi oblasti" [Resolution No. 168-p as of April 9, 2019 "On Approval of the State Programme of Volgograd Region "Development of Tourism in Volgograd region"]. Accessed on: July 17, 2021. [Online]. Available: https://docs.cntd.ru/document/553238455

2. Strategiya sotsialno-ekonomicheskogo razvitiya Volgogradskoi oblasti do 2030 goda [Strategy of Social and Economic Development of Volgograd Region Until 2030]. Accessed on: July 17, 2021. [Online]. Available: https: //economy.gov.ru/material/file/2753c0c8f95af35f9357eb724b635e2c/proekt_strategii.p df

3. T.G. Stefanenko, Etnopsikhologiya [Ethnopsychology] (Aspect Press, Moscow, 2009)

4. A.S. Skripkin, Arkheologicheskoe nasledie Volgogradskoi oblasti [Archaeological Heritage of Volgograd Region] (Izdatel, Volgograd, 2013)

5. E.E. Levkievskaya, Slavyanskii obereg. Semantika i struktura [The Slavic Protective Averter. Semantics and Structure] (Indrik, Moscow, 2002)

6. C.G. Jung, M.-L. Von Franz, J.L. Henderson, Chelovek i ego simvoly [Man and his symbols], in I.N. Sirenko (ed.) (Medkov, Moscow, 2020)

7. L. Levy-Bruhl, Sverkhestestvennoe v pervobytnom myshlenii [The Supernatural in Primitive Thinking] (Pedagogika-Press, Moscow, 1994)

8. A.P. Miksyuk, Civil. Horiz. 10, 285-287 (2019)

9. A.V. Chernyaeva, Evolyutsiya osmysleniya simvola kamnya v psikhologicheskoi praktike [Morphed comprehension of the stone as a symbol in psychological practice] (Logos Centre for Scientific Knowledge, Stavropol, 2016)

10. N.A. Potapova, Rus. Word World, 2, 31-36 (2016)

11. V.N. Telia, D.B. Gudkov, M.L. Kovshova, Bolshoi frazeologicheskii slovar russkogo yazyka [The Big Phraseological Dictionary of the Russian Language] (AST-Press Book, Moscow, 2018)

12. R.A. Tokarev, Rannie formy religii [Early Forms of Religion] (Politizdat, Moscow, 1990)

13. A.V. Chernyaeva. Higher Edu. Today 3, 75-78 (2017)

14. M.-L. Von Franz, Vremya, ritmy i pauzy [Time, Rythms and Pauses] (Phantom-Press, Moscow, 2012)

15. N.A. Potapova, Philol. Sci. Iss. Theory and Prac. 2, 131-135 (2018) 